\title{
Dynamic Behavior of a PEM Fuel Cell During Electrochemical CO Oxidation on a PtRu Anode
}

\author{
Hui Lu · Liisa Rihko-Struckmann • \\ Richard Hanke-Rauschenbach · Kai Sundmacher
}

Published online: 4 November 2008

(c) The Author(s) 2008. This article is published with open access at Springerlink.com

\begin{abstract}
The dynamic behaviour of a single PEM fuel cell (PEMFC) with a PtRu/C anode catalyst using CO containing $\mathrm{H}_{2}$ as anode feed was investigated at ambient temperature. The autonomous oscillations of the cell potential were observed during the galvanostatic operation with hydrogen anode feed containing CO up to $1000 \mathrm{ppm}$. The oscillations were ascribed to the coupling of the adsorption of $\mathrm{CO}$ (the poisoning step) and the subsequent electrochemical oxidation of $\mathrm{CO}$ (the regeneration step) on the anode catalyst. The oscillations were dependent on the $\mathrm{CO}$ concentration of the feed gas and the applied current density. Furthermore, it was found that with CO containing feed gas, the time average power output was remarkably higher under potential oscillatory conditions in the galvanostatic mode than during potentiostatic operation. Accompanying these self-sustained potential oscillations, oscillation patterns of the anode outlet $\mathrm{CO}$ concentration were also detected at low current density $\left(<100 \mathrm{~mA} / \mathrm{cm}^{2}\right)$. The online measurements of the anode outlet $\mathrm{CO}$ concentrations revealed that $\mathrm{CO}$ in the anode $\mathrm{CO} / \mathrm{H}_{2}$ feed was partially electrochemically removed during galvanostatic operation. More than $90 \%$ CO conversion was obtained at the current densities above $125 \mathrm{~mA} / \mathrm{cm}^{2}$ with low feed flow rates $(100-200 \mathrm{~mL} / \mathrm{min})$.
\end{abstract}

H. Lu · L. Rihko-Struckmann $(\bowtie) \cdot$ R. Hanke-Rauschenbach . K. Sundmacher

Max Planck Institute for Dynamics of Complex Technical Systems, Sandtorstrasse 1, 39106 Magdeburg, Germany e-mail: rihko@mpi-magdeburg.mpg.de

K. Sundmacher

Process Systems Engineering, Otto-von-Guericke University Magdeburg, Universitätsplatz 2, 39106 Magdeburg, Germany
Keywords PEMFCs · Potential oscillations · Electrochemical CO removal

\section{Introduction}

The hydrogen gas produced by the steam reforming of light alkanes (e.g., methane) or alcohols is a suitable fuel for $\mathrm{H}_{2}$ polymer electrolyte membrane fuel cells (PEMFCs) [1-3]. However, even traces (ppm) of carbon monoxide (CO) in the hydrogen feed gas can cause serious performance degradation of PEMFCs [1-6]. In order to achieve higher power output with $\mathrm{CO}$ containing feed in fuel cells, the utilisation of bimetallic anode catalysts, PtM/C, have been largely investigated [1-3, 6-12]. The influence of $\mathrm{Ru}, \mathrm{Mo}$, Sn with $\mathrm{Pt}$ as anode catalyst is intensively studied. The enhanced CO-tolerance of $\mathrm{PtRu} / \mathrm{C}$ is generally ascribed to the decrease in $\mathrm{CO}$ binding energy on $\mathrm{Pt}$ due to electronic substrate effects, and to the oxidation of chemisorbed $\mathrm{CO}$ being catalyzed at low potential by the activation of $\mathrm{H}_{2} \mathrm{O}$. The $\mathrm{CO}$ poisoning and recovery processes on the anode are strongly influenced by the kinetics and thermodynamics of either direct or electrochemical oxidation of $\mathrm{CO}$, as well as the physical and chemical adsorption/desorption processes. In addition, because of the strong poisoning of the anode catalyst with $\mathrm{CO}$ at lower temperatures, it is important to investigate the fuel cell performance at room temperature relating to the start-up conditions of the PEM fuel cell system $[2,4]$. Potential oscillations have been previously reported by other groups [2, 4, 10-12], but our goal was to obtain further insight into the $\mathrm{CO}$ poisoning process and into the resulting dynamic characteristics of a cell using CO-containing $\mathrm{H}_{2}$ as anode feed. In fact, the transient recovery of the cell performance is likely related to the fast electrochemical oxidation of the adsorbed $\mathrm{CO}$ occurring 
above certain anode overpotential. Therefore, the removal of the trace amount of $\mathrm{CO}$ in the feed by electrochemical $\mathrm{CO}$ oxidation in a fuel cell type unit could provide an alternative for the conventional preferential oxidation technology with gaseous $\mathrm{CO}$ in the bulky and cost-intensive reactors [2].

He et al. [13] and Lakshmanan et al. [14] reported the pioneering investigations of the $\mathrm{CO}$ oxidative conversion in PEMFC-type configurations. Recently, the electrochemical preferential oxidation (EPrOx) of $\mathrm{CO}$ has been intensively studied by Zhang et al. [2, 15]. Their results demonstrated that $\mathrm{CO}$ in the anode feed was partly removed by the electrochemical oxidation of $\mathrm{CO}$ in the anodic electrode. Therefore, aside from the power generation by hydrogen oxidation, these results clearly indicate that $\mathrm{CO}$ is oxidised both on the anode in PEM fuel cells and under mild operation conditions. Huang et al. [3] presented an analogous concept for $\mathrm{CO}$ treatment, in which the COcontaining reformate hydrogen was conducted in an Adsorber/Electrolyzer/Humidifier reactor unit similar to a MEA structure before feeding it into PEMFCs. The results showed that the PEMFC performance was improved because of the removal of $\mathrm{CO}$ in the fuel feed, although the experimentally measured $\mathrm{CO}$ conversion was not reported. Ioroi et al. [1] observed a remarkable increase in the anode outlet $\mathrm{CO}$ concentrations in a PEMFC with $\mathrm{PtRu} / \mathrm{C}$ anode catalyst due to the high utilisation degree of the hydrogen fuel in the feed gas. However, with the $\mathrm{Pt}-\mathrm{MoO}_{x} / \mathrm{C}$ anode catalyst $\mathrm{CO}$ was also efficiently removed at $80{ }^{\circ} \mathrm{C}$ at a given current density. These observations demonstrate that it is crucial to understand the $\mathrm{CO}$ transient poisoning/ recovery mechanism and $\mathrm{CO}$ electrochemical oxidation process occurring with the $\mathrm{CO}$-containing $\mathrm{H}_{2}$ anodic feed.

To get deeper insight into the influence of $\mathrm{CO}$ on the poisoning of the anode catalyst and the resulting dynamic behaviour of the cell potential, we compared the steadystate polarization performance (potentiostatic $V-i$ curves) to the galvanostatic operation with a single fuel cell using $\mathrm{H}_{2}$ containing different $\mathrm{CO}$ concentration (0-1000 ppm) as anode feed. The dynamic behaviour (the self-sustained potential oscillations) of the fuel cell voltage during galvanostatic operation is reported at various applied current densities. Furthermore, a quantitative on-line determination of the CO concentration in the anode outlet gas stream during the self-sustained potential oscillations is reported as well. Finally, we evaluate the feasibility of a PEM fuel cell with a bimetallic anode catalyst to work as a reactor unit for removing traces of $\mathrm{CO}$ in the $\mathrm{H}_{2}$ stream.

\section{Experimental}

The experiments were carried out in a single cell with an active electrode area of $26 \mathrm{~cm}^{2}$ equipped with membrane electrode assembly (MEA) prepared in-house. The catalyst layers (anode: carbon supported 30\% PtRu (atomic ratio 1:1) with $0.75 \mathrm{mg} / \mathrm{cm}^{2}$ metal loading; cathode: unsupported Pt black with $5 \mathrm{mg} / \mathrm{cm}^{2}$ loading) were fixed on the commercial Nafion 117 membrane foil by airbrush technique as described in detail in a prior publication of our group [16]. The commercial catalysts were purchased from the Alfa Aesar ${ }^{\circledR}$ Johnson Matthey (Germany). The graphite bipolar plates had parallel flow-field channels illustrated photographically in [16]. The PEMFCs were completed by gold-plated copper plates as current collectors and stainless plates for bracing the whole sandwich structure.

The experimental setup consisted of calibrated rotameters to conduct the reactant gases $\left(\mathrm{H}_{2}\right.$ containing ppm level of $\mathrm{CO})$ to the anodic $(f=100-400 \mathrm{~mL} / \mathrm{min})$ and to the cathodic (pure $\mathrm{O}_{2}, f=300 \mathrm{~mL} / \mathrm{min}$ ) compartments as shown in Fig. 1 The $\mathrm{CO}$ concentration in the $\mathrm{CO} / \mathrm{H}_{2}$ fuel was varied by diluting a premixed gas containing $1000 \mathrm{ppm}$ of $\mathrm{CO}$ in $\mathrm{H}_{2}$ with pure $\mathrm{H}_{2}$. The anode and cathode feed streams were humidified by saturating them with moisture at room temperature in bubble bottles. All the experiments in this work were carried out under atmospheric pressure at room temperature without further thermostatic equipments.

An electrochemical workstation (IM6e, Zahner-Elektrik $\mathrm{GmbH}$, Germany) equipped with an external booster (EL101, Zahner-Elektrik GmbH, Germany) was used for the potentiostatic or galvanostatic electrochemical analysis and for the exploration of the transient behavior of the system. An additional in-house constructed, multi-channel potential recorder (with a sampling interval of $1 \mathrm{~s}$ ) was used to record the cell potential as a function of time.

The concentrations of $\mathrm{CO}$ in the anode inlet and outlet gases were analysed with an online infra red $\mathrm{CO}$ gas analyzer (URAS 14, ABB Automation GmbH, Germany) with a measurement range of $0-250 \mathrm{ppm} \mathrm{CO}$. The moisture of the anode outlet gas was removed by conducting the exit gas first through a cooling trap $\left(0{ }^{\circ} \mathrm{C}\right.$, $\sim 33 \mathrm{~mL})$ and subsequently through a silica-gel column ( $\sim 10 \mathrm{~mL}$, estimated void fraction of 0.5 ) before permitting it to enter the moisture-sensitive chamber in the IR analyzer.

\section{Results and Discussion}

\subsection{Cell Performance with $\mathrm{CO}$ Containing $\mathrm{H}_{2}$ Anode Feed}

Figure $2 \mathrm{a}$ shows the cell voltage as a function of the current density obtained in the potentiostatic mode with various concentration levels (50-1000 ppm) of $\mathrm{CO}$ in $\mathrm{H}_{2}$ as anode feed. The polarization curve measured without $\mathrm{CO}$ 
Fig. 1 Experimental setup and electrochemical workstations of EPrOx unit

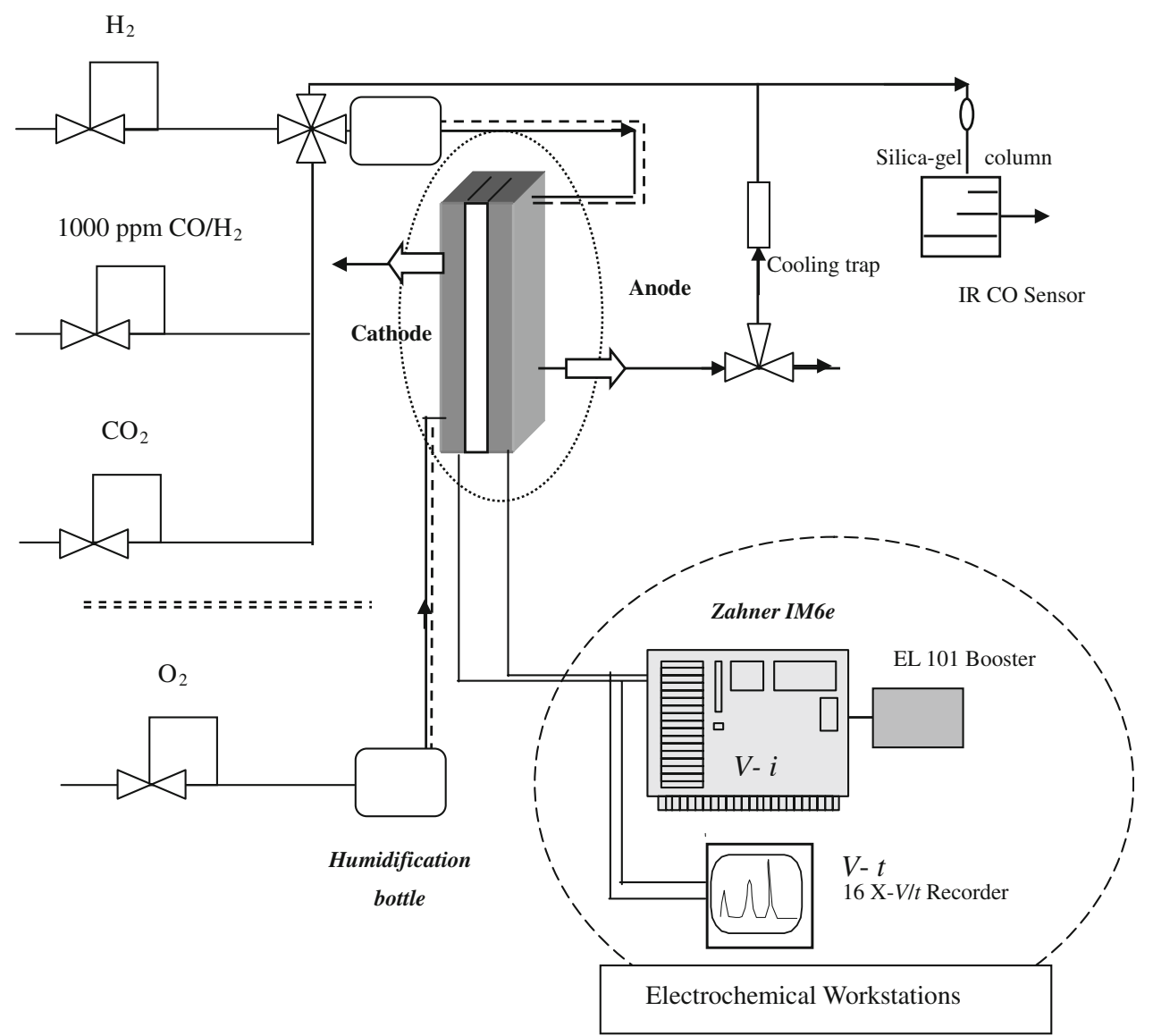

in the $\mathrm{H}_{2}$ feed is also presented here for comparison. The open-circuit voltage (OCV) of the fuel cell with $\mathrm{CO}$ free $\mathrm{H}_{2}$ feed was $\sim 1.03 \mathrm{~V}$. The highest power density obtained was $\sim 150 \mathrm{~mW} / \mathrm{cm}^{2}$ at a current density of $\sim 325 \mathrm{~mA} / \mathrm{cm}^{2}$ (Fig. 2b), which demonstrates a good operating performance of the fuel cell with $\mathrm{CO}$-free $\mathrm{H}_{2}$ feed at room temperature. However, as expected, the fuel cell performance decreased significantly when CO-containing gas was fed to the anode compartment. Remarkable voltage loss was observed immediately, as trace amounts of $\mathrm{CO}$ were included in the anode feed gas. The dependence of the measured cell voltage on the $\mathrm{CO}$ concentration in the anode gas and on the current density was strongly nonlinear as seen in Fig. 2a. For example, at a current density of $25 \mathrm{~mA} / \mathrm{cm}^{2}$, the cell voltage was $\sim 0.89 \mathrm{~V}$ with pure $\mathrm{H}_{2}$ as anode feed. The cell voltage decreased sharply in the current density range between 0 and $25 \mathrm{~mA} / \mathrm{cm}^{2}$ and was $\sim 0.47$ and $0.40 \mathrm{~V}$ with anode fuel gas containing 200 and $1000 \mathrm{ppm}$ CO in hydrogen, respectively. The obvious decrease in the fuel cell power output is due to the strong adsorption of $\mathrm{CO}$ which occupies the active sites of the anode catalysts in a potentiostatic controlled system, in this way hindering the electrochemical oxidation of hydrogen $[1-3,6]$.

\subsection{Onset of the Autonomous Potential Oscillations}

Figure 3 illustrates the cell voltage behaviour in the galvanostatic operation as a function of time as the anode feed was switched between $\mathrm{CO}$ free hydrogen and $\mathrm{CO}$ containing (200 ppm) hydrogen at a current density of $100 \mathrm{~mA} / \mathrm{cm}^{2}$. As expected, the cell voltage remained unchanged, high level using $\mathrm{CO}$ free $\mathrm{H}_{2}$ feed (not shown here). However, the autonomous oscillations of the fuel cell potential were observed in the galvanostatic operation when $\mathrm{CO}$-free $\mathrm{H}_{2}$ stream was replaced by $\mathrm{CO} / \mathrm{H}_{2}$ stream with $200 \mathrm{ppm} \mathrm{CO}$. This observation is in full accordance with the results previously reported by Zhang and Datta $[2,10]$. When the CO containing $\mathrm{H}_{2}$ stream was replaced by the $\mathrm{CO}$ free $\mathrm{H}_{2}$ stream, the potential oscillations disappeared, the cell operation was gradually revived, and the cell voltage was recovered to the initial value obtained with the CO-free hydrogen. These results clearly indicate that the poisoning process is not completely irreversible, and that the investigated cell could be regenerated during 20 min by operating with CO-free hydrogen to the cell. The observed performance recovery is likely due to the gradual desorption of the adsorbed $\mathrm{CO}$ molecules from the $\mathrm{PtRu} / \mathrm{C}$ active sites. The following mechanism has been suggested for the re-activation of the CO-poisoned sites [1-4]: 

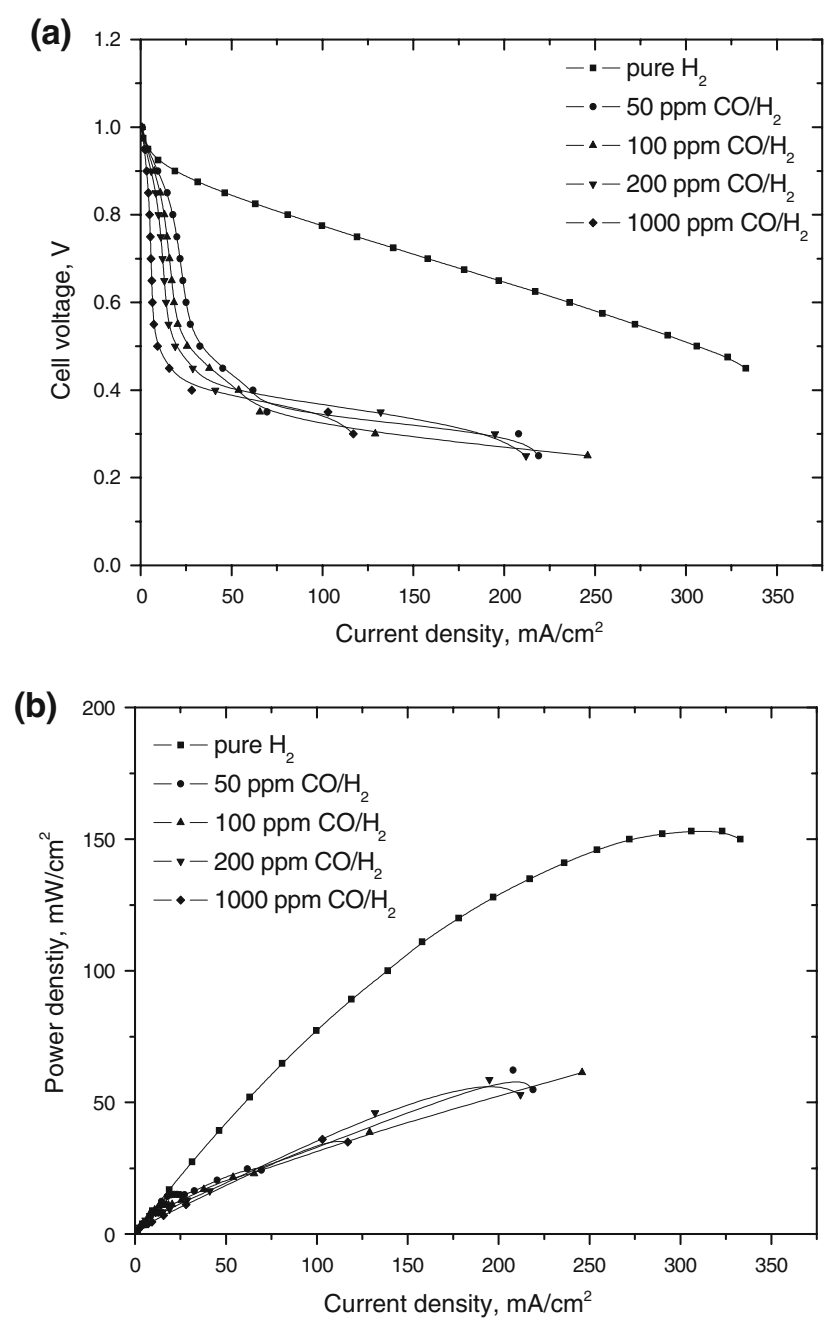

Fig. 2 Potentiostatic polarization and power density curves of a single cell with different $\mathrm{CO}$ concentrations $\mathrm{CO} / \mathrm{H}_{2}$ as anode feed, anodic feed flow rate: $f=300 \mathrm{~mL} / \mathrm{min}$

$$
\begin{aligned}
& \mathrm{CO}-\mathrm{S} \rightarrow \mathrm{CO}+\mathrm{S} \\
& \mathrm{CO}-\mathrm{S}+\mathrm{O}-\mathrm{S} \rightarrow \mathrm{CO}_{2}+2 \mathrm{~S} \\
& \mathrm{CO}-\mathrm{S}+\mathrm{HO}-\mathrm{S} \rightarrow \mathrm{CO}_{2}+\mathrm{H}^{+}+\mathrm{e}^{-}+2 \mathrm{~S} \\
& \mathrm{CO}-\mathrm{S}+\mathrm{H}_{2} \mathrm{O}-\mathrm{S} \rightarrow \mathrm{CO}_{2}+\mathrm{H}_{2}+2 \mathrm{~S}
\end{aligned}
$$

where $\mathrm{S}$ represents the adsorption active sites of the $\mathrm{PtRu} / \mathrm{C}$ anode catalyst. Equation 1 describes the direct desorption processes, and Eq. 2 the direct oxidation of $\mathrm{CO}$, Eq. 3 the electrochemical oxidation of $\mathrm{CO}$, and Eq. 4 the water-gas-shift (WGS) reaction, respectively. Considering the operation conditions in this study (room temperature), the dynamic recovery is likely related to the electrochemical $\mathrm{CO}$ oxidation process. This would mean that-depending on the anode potential-the adsorbed $\mathrm{CO}$ reacts on the $\mathrm{PtRu} / \mathrm{C}$ active sites according to Eq. 3.
3.3 The Influence of the Current Density on Potential Oscillations

In order to analyse the potential oscillations observed with CO containing feed gas, the dependence of the oscillations on the applied current density and on the feed flow rate was investigated in more detail. Figure 4 illustrates the oscillation patterns (time duration: $300 \mathrm{~s}$ ) of the fuel cell using $\mathrm{H}_{2}$ with $200 \mathrm{ppm} \mathrm{CO}$ as anode feed at various current densities between 0 and $200 \mathrm{~mA} / \mathrm{cm}^{2}$. The voltage remained expectedly stable at a value of $1.03 \mathrm{~V}$ during the initial conditions without current (open-circuit condition). The autonomous oscillations of the cell potential were observed when a current density of $25 \mathrm{~mA} / \mathrm{cm}^{2}$ or higher was applied to the system. At the lower current range, $<100 \mathrm{~mA} / \mathrm{cm}^{2}$, the oscillations occurred with a constant frequency, and showed nearly constant amplitude over time at each measured current density. At higher current densities, $>100 \mathrm{~mA} / \mathrm{cm}^{2}$, the frequency remained constant at each measured current density, but the amplitude showed noticeable fluctuations. The frequency was clearly dependent on the current density, and was found to increase nearly linearly as a function of the applied current densities (as seen in Fig. 4). It should be pointed out here that the observed dependence of the oscillation frequency on the current density, which was obvious in our measurements, was not detected in the earlier investigations by Zhang and Datta [10]. The reason for the performance difference might be attributed to the different current density range or to the operation temperature. Our measurements were carried out at room temperature without the external thermostating at the current density range up to $200 \mathrm{~mA} /$ $\mathrm{cm}^{2}$. In comparison to our experimental conditions, Zhang and Datta [10] investigated the influence of the current density at the cell temperature of $55{ }^{\circ} \mathrm{C}$ with current densities from 300 up to $700 \mathrm{~mA} / \mathrm{cm}^{2}$. Furthermore, the different behaviour observed here might be related to the cell size: $26 \mathrm{~cm}^{2}$ (this study) vs. $5 \mathrm{~cm}^{2}$ in [10], whereas the larger anode compartment in our system might cause more complex, non-ideal flow distribution [17-19]. However, more detailed experiments and multidimensional modelling will be carried out later to elucidate the influence of the different flow fields/electrode areas on the cell potential oscillations in detail.

As mentioned above, the potential oscillation patterns are likely related to the $\mathrm{CO}$ adsorption and the electrooxidation processes in the anode $\mathrm{PtRu} / \mathrm{C}$ catalyst surface. Initially, at low CO coverage, the cell generates the desired current at high cell voltage (i.e., low anodic overpotential). As the $\mathrm{CO}$ coverage increases, the current remains constant but the cell voltage rapidly decreases due to the continuously increasing anodic overpotential. The adsorbed $\mathrm{CO}$ is then electrochemically oxidised on the anode catalyst 
Fig. 3 Transient behaviour of $\mathrm{CO}$ poisoning and performance recovery with $200 \mathrm{ppm} \mathrm{CO} / \mathrm{H}_{2}$ and pure $\mathrm{H}_{2}$ using cyclic feed. $f=300 \mathrm{~mL} / \mathrm{min}, j=100 \mathrm{~mA} /$ $\mathrm{cm}^{2}$. The inset is the magnified pattern of the self-sustained potential oscillations in the corresponding potential region

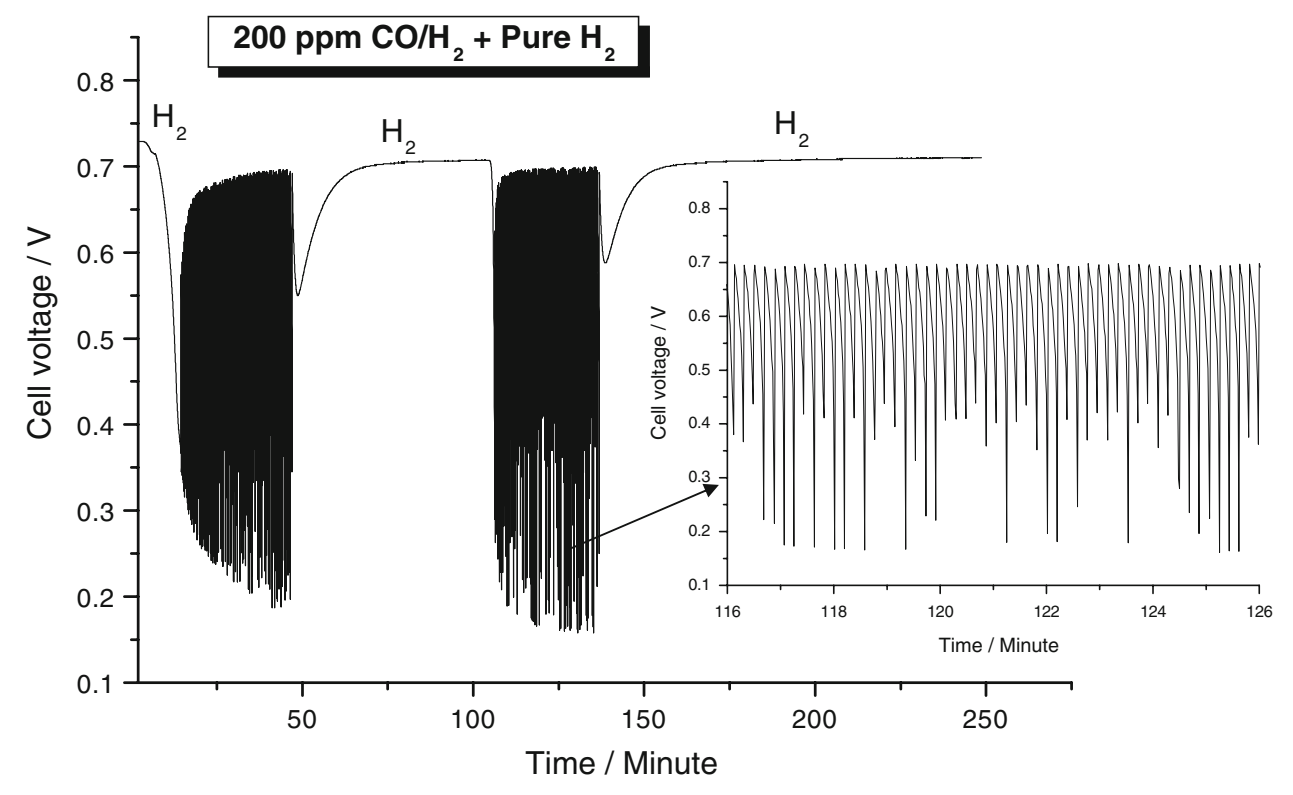

surface above a certain limiting overpotential. This in turn releases the active sites earlier occupied by $\mathrm{CO}[10,20$ 23]. The simple dynamic modelling proposed by Zhang and Datta [10] was mainly based on this mechanism and was able to successfully describe most experimental observations.

\subsection{Improved Cell Performance Under the Oscillatory- State Operation}

Figure 5a depicts the amplitude of the potential oscillations as a function of applied current densities with $200 \mathrm{ppm} \mathrm{CO} / \mathrm{H}_{2}$ feed stream. The time-averaged voltage was calculated for each applied current density (as illustrated also in Fig. 5a), and the polarization curve in the galvanostatic operating mode was determined on the basis on this time-averaged value. Figure $5 \mathrm{~b}$, c illustrate the polarization and the power density curves under the potentiostatic and galvanostatic operation modes (corresponding to the potential steady-state and potential oscillatory-state). For comparison, in Fig. $5 \mathrm{~b}$, c, the $V-i$ curve and the power output for $\mathrm{CO}$-free hydrogen under potentiostatic conditions is also shown. As can be seen in Fig. 5b, with $\mathrm{CO}$ containing feed gas the time-averaged voltage at the applied current density in the galvanostatic mode is clearly higher than the corresponding value in the potentiostatic mode.

\subsection{Anode Outlet CO Concentrations/Electrochemical CO Removal}

The anode outlet $\mathrm{CO}$ concentrations were experimentally determined by an IR CO gas analyzer as a function of the current density applied $\left(0-200 \mathrm{~mA} / \mathrm{cm}^{2}\right)$. If the fuel cell was operated in the low current density range $(<100 \mathrm{~mA} /$ $\mathrm{cm}^{2}$ ), the CO concentration in the reactor outlet was found to oscillate (as seen in Fig. 6a). Figure 6b illustrates the experimentally determined signal amplitudes of the $\mathrm{CO}$ concentration at various applied current densities. The frequency of the concentration oscillations was approximately equal to that of the cell potential oscillations. This observation makes it evident that aside from the hydrogen oxidation, the $\mathrm{CO}$ is also electrochemically oxidised on the anodic electrode.

As the measured $\mathrm{CO}$ concentration oscillations were found to be dependent on the current density, and as they were experimentally detectable only in the lower current density range (low frequency), we should briefly describe the analytical procedure applied here for the $\mathrm{CO}$ analysis. IR-spectroscopy is a very precise detection method even for small concentrations (ppm range) of CO. However, due to the limited absorbance of IR light by gas molecules, a certain light path (and the measurements chamber volume) is necessary in the IR equipment. Furthermore, due to the high sensitivity of the IR chamber windows (typically $\mathrm{KBr}$ ) to humidity, the incoming gas has to be completely dehumidified before conducting it into the equipment. The water was removed in a cooling trap $\left(0{ }^{\circ} \mathrm{C}\right)$ followed by a column filled with the silica gel. All three units (the cooling trap, the silica gel column and IR measurement chamber) possess certain volumes, which inevitably causes some back mixing of the gas stream. The back mixing would not be critical in steady-state measurements where the concentrations on the reactor outlet remain constant over time. However, during the signal oscillating conditions as 

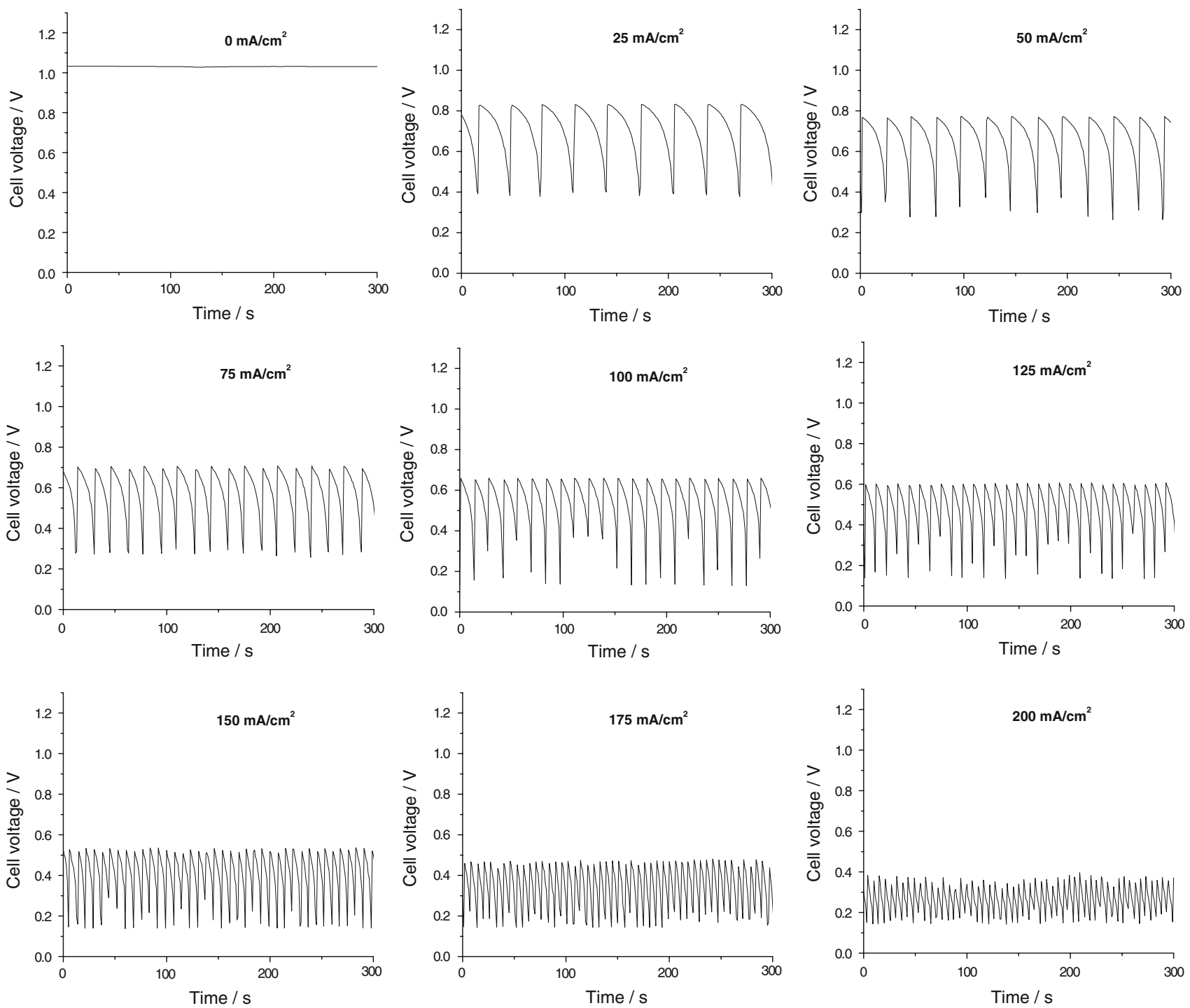

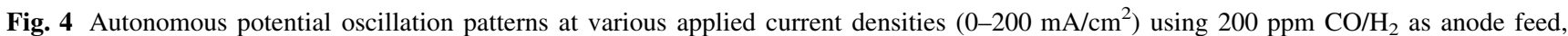
$f=300 \mathrm{~mL} / \mathrm{min}$

measured here, the back mixing dramatically influences the measured signal amplitude. We might expect here that the measured signal amplitude $\hat{x}_{C O}^{\text {meas }}$ is depressed due to the internal back mixing in each of the three units in the cascade, and therefore the measured signal amplitude is smaller than the actual reactor outlet amplitude $\hat{x}_{C O}^{\text {reactor }}$. The ratio of the measured/actual amplitudes can be roughly estimated by a simple mathematical model. For this purpose the three units are treated as a cascade of ideally mixed tanks (volumes approximately 33, 5 and $22 \mathrm{~mL}$ ). Ideal tubular flow behavior (no back mixing) is assumed in the tubular lines (i.d. $1 \mathrm{~mm}$ ) between the tanks. Furthermore, the $\mathrm{CO}$ concentration signal is approximated by a harmonic oscillation. The signal amplitudes can then be related by the frequency response of the cascade (e.g., [24]):

$$
\begin{aligned}
& \frac{\hat{x}_{C O}^{\text {reactor }}(\omega)}{\hat{x}_{C O}^{\text {meas }}(\omega)}=\left|G(\omega)^{-1}\right| \\
& \quad \text { with } G(\omega)=\frac{\exp (-\theta j \omega)}{\left(\tau_{1} j \omega+1\right)\left(\tau_{2} j \omega+1\right)\left(\tau_{3} j \omega+1\right)} .
\end{aligned}
$$

In the above equation $\omega$ is the angular frequency of the signal, $\tau_{1}-\tau_{3}$ are the time constants of the three tanks (tank volume divided by volumetric flow rate) and $\theta$ is the dead time of the tubular lines. The last parameter however has no influence on the modulus of the frequency response function and therefore does not influence the amplitude ratio of the cascade input and output signal.

Figure $6 \mathrm{~b}$ shows the amplitude of the measured $\mathrm{CO}$ concentration oscillations, $\hat{x}_{C O}^{\text {meas }}$. They were found to decrease with increasing current density. No oscillations were experimentally observed in the $\mathrm{CO}$ signal at current 

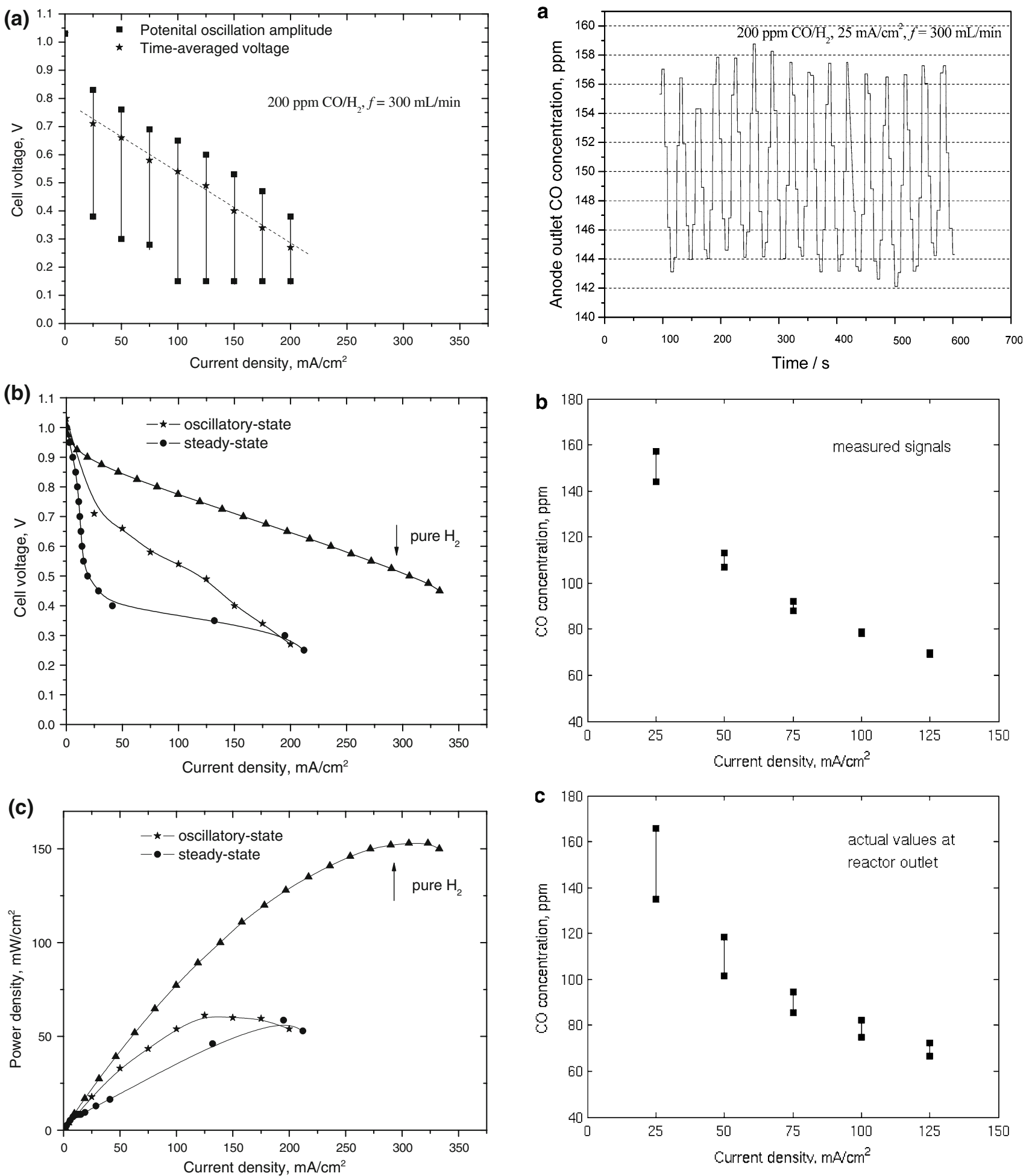

Fig. 5 Comparison of the polarization characteristics and power density curves under the steady-state (the potentiostatic mode) and oscillatory-state (the galvanostatic mode) operations using $200 \mathrm{ppm}$ $\mathrm{CO} / \mathrm{H}_{2}$ as anode feed for a single cell, $f=300 \mathrm{~mL} / \mathrm{min}$

densities higher than $125 \mathrm{~mA} / \mathrm{cm}^{2}$. As can be seen from Fig. 6c, the calculated signal amplitudes at the reactor outlet, $\hat{x}_{C O}^{\text {reactor }}$, also decrease with increasing current

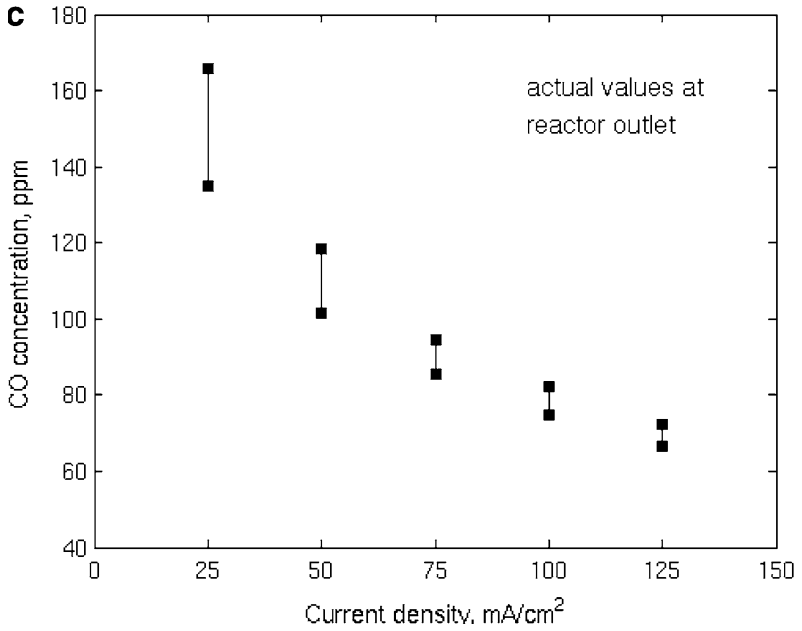

Fig. 6 Anode outlet CO concentration oscillations (a) at a current density of $25 \mathrm{~mA} / \mathrm{cm}^{2}(f=300 \mathrm{~mL} / \mathrm{min})$, the measured oscillation amplitudes (b) and the estimated oscillation amplitudes (c) of the anode outlet $\mathrm{CO}$ concentration at various current densities applied $(f=300 \mathrm{~mL} / \mathrm{min})$

density. As, the frequency of the oscillations is increasing as a function of the current density (see Fig. 4), the attenuation of the cascade is also increasing. This fact 
allows us to expect that the $\mathrm{CO}$ concentration in the reactor outlet likely oscillates at higher current densities as well. For current densities higher than $125 \mathrm{~mA} / \mathrm{cm}^{2}$, the potential frequency was found to be higher than $0.1 \mathrm{~Hz}$. This value lies considerably above the cut-off frequency of the cascade. It is therefore not possible to resolve the $\mathrm{CO}$ concentration oscillations at higher current densities with the present analysis system.

The average concentration of $\mathrm{CO}$ in the anode outlet (based on the maximum and minimum $\mathrm{CO}$ concentrations) was calculated for each experimental conditions. Figure $7 \mathrm{a}$ presents the measured average outlet $\mathrm{CO}$ concentrations when 200 ppm CO containing $\mathrm{H}_{2}$ was used as anode feed stream at various current densities of $25-200 \mathrm{~mA} / \mathrm{cm}^{2}$. As expected, under open circuit conditions, the anode outlet $\mathrm{CO}$ concentration was equal to the inlet $\mathrm{CO}$ concentration. This agrees with the reported observation that $\mathrm{CO}$ does not react in the anode chamber under open circuit conditions. This was also observed by Ioroi et al. [1], as they reported
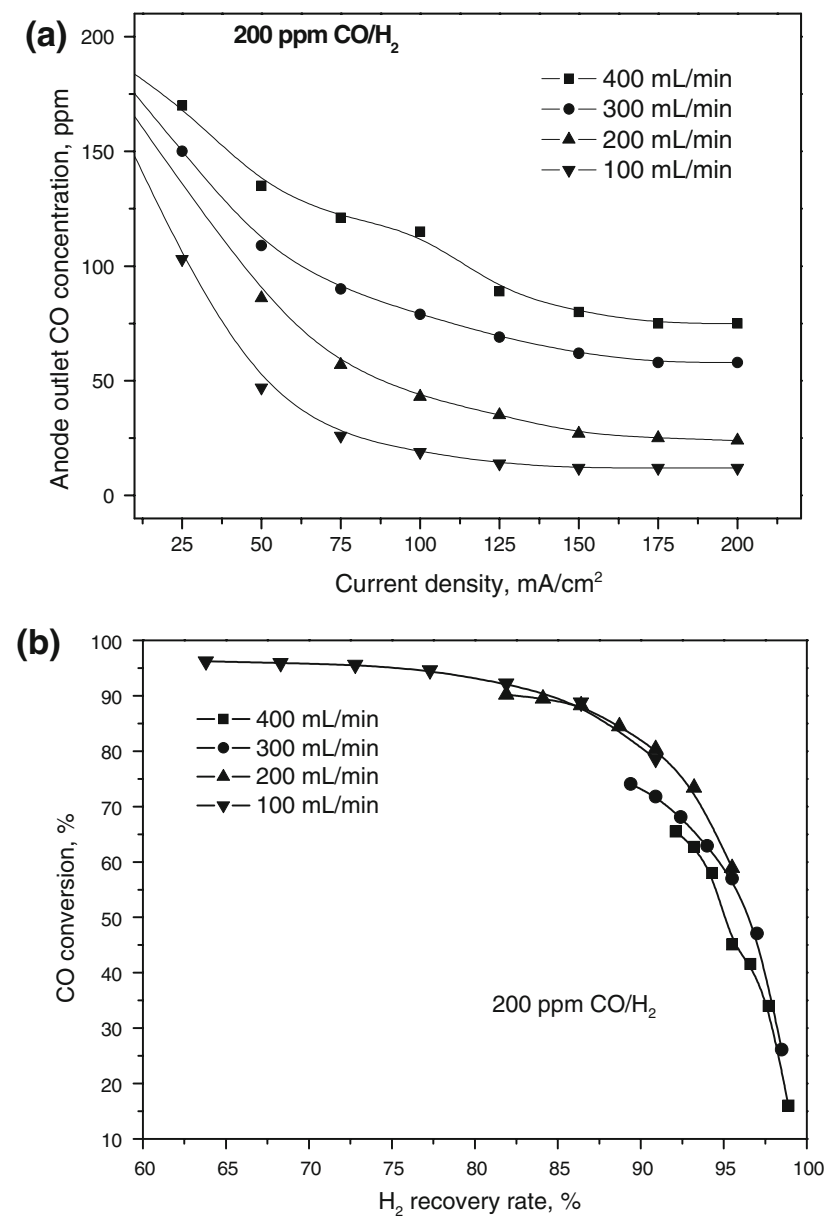

Fig. 7 The anode CO outlet concentrations (a) at various current densities with different anode flow rates and the dependence of $\mathrm{CO}$ conversion on the hydrogen recovery rate (b) using $200 \mathrm{ppm} \mathrm{CO} / \mathrm{H}_{2}$ as anode feed for a single fuel cell, $f=100-400 \mathrm{~mL} / \mathrm{min}$ that the anode outlet $\mathrm{CO}$ concentrations for $\mathrm{PtRu} / \mathrm{C}$ catalyst were nearly equal to the inlet values, and the outlet $\mathrm{CO}$ concentrations were hardly affected by the species of the cathode feed (pure $\mathrm{O}_{2}$ or pure $\mathrm{N}_{2}$ stream) under the opencircuit conditions. However, under conditions where current was applied, we found that the $\mathrm{CO}$ concentration steadily decreased as a function of the current density from 25 to $200 \mathrm{~mA} / \mathrm{cm}^{2}$ at a constant flow rate. For $200 \mathrm{ppm}$ $\mathrm{CO} / \mathrm{H}_{2}$ with a flow rate of $300 \mathrm{~mL} / \mathrm{min}$, the anode outlet CO concentrations were 150, 109, 79, 62 and $58 \mathrm{ppm}$, respectively, at the current densities of 25, 50, 100, 150 and $200 \mathrm{~mA} / \mathrm{cm}^{2}$, respectively. At current densities $>125 \mathrm{~mA} /$ $\mathrm{cm}^{2}$, only minor differences were observed in the $\mathrm{CO}$ conversion. Furthermore, the anode outlet $\mathrm{CO}$ concentrations were found to decrease with increasing residence time at a given current density. For example, for $200 \mathrm{ppm} \mathrm{CO} /$ $\mathrm{H}_{2}$ as anode feed, the anode outlet $\mathrm{CO}$ concentrations were $115,79,43$ and 19 ppm corresponding to the flow rates of 400, 300, 200 and $100 \mathrm{~mL} / \mathrm{min}$ at the current density of $100 \mathrm{~mA} / \mathrm{cm}^{2}$. If we take into consideration the hydrogen fuel utilisation degree at the above flow rates $(4.9,6.59$, $9.88,19.8 \%$ ) we observe a clear, non-linear dependence of the $\mathrm{CO}$ conversion from the hydrogen utilisation degree. $\mathrm{CO}$ conversion increases as the hydrogen utilisation degree increases, but due to the non-linear dependency, high $\mathrm{CO}$ conversion is possible only with very high utilisation degree. At current density $200 \mathrm{~mA} / \mathrm{cm}^{2}$, the anode outlet $\mathrm{CO}$ concentration decreased from 75 to $12 \mathrm{ppm}$ as the anode flow rate decreased from 400 to $100 \mathrm{~mL} / \mathrm{min}$. The observed low $\mathrm{CO}$ outlet concentration in the cell outlet stream clearly indicates that $\mathrm{CO}$ in the anode feed was partly converted to $\mathrm{CO}_{2}$ by the electrochemical oxidation of $\mathrm{CO}$ in the anode. Finally, the dependence of $\mathrm{CO}$ conversion on the hydrogen recovery degree (calculated as the ratio of unconsumed $\mathrm{H}_{2}$ to the feed of $\mathrm{H}_{2}$ ) is given in Fig. 7b. The ideal operating point for the system would be in the right upper corner in this graph, where the high CO conversion is achieved with simultaneous high hydrogen recovery. However, as seen in the illustration, the conversion of $\mathrm{CO}$ was found to decrease with the high recovery degree of $\mathrm{H}_{2}$. The optimum operating point (high $\mathrm{H}_{2}$ recovery degree, high $\mathrm{CO}$ conversion) with the investigated cell was achieved at the lowest investigated feed rate $(100 \mathrm{~mL} / \mathrm{min})$ with moderate current density $\left(50-75 \mathrm{~mA} / \mathrm{cm}^{2}\right)$, where the conversion of $\mathrm{CO}$ was approximately $75-85 \%$ and the $\mathrm{H}_{2}$ recovery degree 85 to $90 \%$.

\section{Conclusions}

The PEMFC cell performance with the PtRu/C anode catalyst using various $\mathrm{CO}$ concentrations (0-1000 ppm) in the $\mathrm{CO} / \mathrm{H}_{2}$ anodic feed was investigated at room 
temperature and atmospheric pressure. The self-sustained oscillations of the cell voltage were observed under the galvanostatic operation with $\mathrm{CO}$-containing $\mathrm{H}_{2}$ anodic feed. The $\mathrm{CO}$ concentration oscillations in the anode outlet gases were also experimentally observed at low current densities $\left(<100 \mathrm{~mA} / \mathrm{cm}^{2}\right)$ for the first time, which directly proves the occurrence of the electrochemical oxidation of $\mathrm{CO}$ in the anode field. The quantitative analysis of the anode outlet $\mathrm{CO}$ concentration demonstrated that $\mathrm{CO}$ in the anodic feed was removed by the electrochemical CO oxidation accompanied by the periodical potential oscillations. Therefore, we might suggest here that a low temperature fuel cell equipped with PtRu anode could possibly work as an electrochemical membrane reactor for the removal of traces of $\mathrm{CO}$ in the $\mathrm{H}_{2}$ streams.

Acknowledgements Dr. Hui $\mathrm{Lu}$ is grateful for a Max Planck Scholarship from the Max-Planck-Gesellschaft (MPG). The financial support obtained from the co-operation project ProBio between the Max Planck Society and Fraunhofer Society is gratefully acknowledged.

Open Access This article is distributed under the terms of the Creative Commons Attribution Noncommercial License which permits any noncommercial use, distribution, and reproduction in any medium, provided the original author(s) and source are credited.

\section{References}

1. Ioroi T, Akita T, Yamazaki SI, Siroma A, Fujiwara N, Yasuda K (2006) Electrochim Acta 52:491

2. Zhang JX, Datta R (2005) J Electrochem Soc 152:A1180
3. Huang CP, Jiang RC, Elbaccouch M, Muradov N, Fenton J (2006) J Power Sources 162:563

4. Jimenez S, Soler J, Valenzuela RX, Daza L (2004) J Power Sources 151:69

5. Litster S, McLean KG (2004) J Power Sources 130:61

6. Wee JH, Lee KY (2006) J Power Sources 157:128

7. Crabb EM, Marshall R, David T (2000) J Electrochem Soc 147:A4440

8. Papageorgopoulos DC, Keijzer M, de Bruijn FA (2002) Electrochim Acta 48:197

9. Bonakdarpour A, Lobel R, Atanasoski RT, Vernstrom GD, Schmoeckel AK, Debe MK, Dahn JR (2006) J Electrochem Soc 153:A1835

10. Zhang JX, Datta R (2002) J Electrochem Soc 149:A1423

11. Murthy M, Esayian M, Hobson A, MacKenzie S, Lee WK, Van Zee JW (2001) J Electrochem Soc 148:A1141

12. Zhang JX, Fehribach JD, Datta R (2004) J Electrochem Soc 151:A689

13. He CZ, Kunz HR, Fenton JM (2001) J Electrochem Soc 148:A1116

14. Lakshmanan B, Huang W, Weidner JW (2002) Electrochem Solid-State Lett 5:A267

15. Zhang JX, Datta R (2003) Electrochem Solid-State Lett 6:A5

16. Schultz T, Sundmacher K (2005) J Power Sources 145:435

17. Stumper J, Campbell SA, Wilkinson DP, Johnson MC, Davis M (1998) Electrochim Acta 43:3773

18. Kanezaki T, Li XG, Baschuk JJ (2006) J Power Sources 162:415

19. Brett DJL, Aguiar P, Brandon NP, Kucernak AR (2007) Int J Hydrogen Energy 32:863

20. Zhang JX (2004) PhD thesis, Worcester Polytechnic Institute, Worcester, pp 92-154, 179-205

21. Zhang JX, Datta R (2004) Electrochem Solid-State Lett 7:A37

22. Thomason AH, Lalk TR, Appleby AJ (2004) J Power Sources 135:204

23. Farrell CG, Gardner CL, Ternan M (2007) J Power Sources $171: 282$

24. Bequette BW (1998) Process dynamics: modeling, analysis, and simulation. Prentice Hall PTR, Upper Saddle River, NJ 